10. Yakubiv, V.M., Gorokhskaia, N.I., and R.D. Yakubiv. "Management model for the development of agricultural enterprises through the introduction of diversification processes." Accelatory problems of the economy, no. 8, 2015, pp. 58-66.

11.Yakubiv, V.M., and I.I. Borishkevich. "Strategic set as an integral tool for the development of agricultural enterprises." Problems of the economy, no. 1, 2017, pp. 157-161.

\title{
Рецензенти:
}

Якубів В.М. - доктор економічних наук, професор, завідувач кафедри управління та бізнесадміністрування ДВНЗ “Прикарпатський національний університет імені Василя Стефаника”;

Жук О.I. - кандидат економічних наук, доцент, доцент кафедри обліку та аудиту ДВНЗ “Прикарпатський національний університет імені Василя Стефаника”.

УДК 37.035:316.46:378

ББК 75.58

\section{СУЧАСНІ ТЕОРІЇ ЛІДЕРСТВА В ОСВІТНІЙ ГАЛУЗІ}

Грібович А. Л.

ДВНЗ "Прикарпатський національний університет імені Василя Стефаника", Міністерство освіти і науки України, кафедра управління та бізнес-адміністрування вул. Шевченка, 57, м. Івано-Франківськ, 76018, Україна, тел.: +380971841940, e-mail: anna.serce4@gmail.com

Анотація. В умовах інформаційного суспільства крім інформації важливим є людський капітал. Тому на розвиток сучасної економіки впливає ефективність освітньої галузі. У результаті висуваються підвищені вимоги особливо до вищої освіти, іiї ефективної організації та управління. В управлінні людськими ресурсами важливе місце посідає інститут лідерства. 3 цією метою систематизовано сучасні трансформації теорій лідерства. Здійснено їх проекцію на освітню галузь. Запропонована класифікація лідерів у закладах вищої освіти.

Ключові слова: менеджмент, лідер, теорії лідерства, освітнє лідерство, заклад вищої освіти.

\section{MODERN THEORIES OF LEADERSHIP IN THE EDUCATIONAL INDUSTRY}

Gribovych A. L.

State Higher Educational Establishment

"Vasyl Stefanyk Precarpathian National University",

Ministry of Education and Science of Ukraine,

Department of Management

and Business Administration,

Shevchenko str., 57, Ivano-Frankivsk,

76018, Ukraine,

tel.: +380971841940,

e-mail: anna,serce4@gmail.com 


\begin{abstract}
In the conditions of information society, in addition to information, human capita is important. Therefore, on the development of the modern economy the efficiency of the educational sector is influenced. As a result, higher requirements are put forward especially for higher education its effective organization and management. In the management of human resources, an institution of leadership plays an important role. For this aim, modern transformations of leadership theories are systematized. Their projection on the educational branch is performed. The classification of leaders in higher education institutions is proposed.
\end{abstract}

Key words: management, leader, theory of leadership, educational leadership, institution of higher education.

Вступ. Глобалізаційні зміни вплинули на світові суспільно-економічні процеси. Відбувся перехід від індустріального суспільства до інформаційного, у якому пріоритетна економіка знань. Крім інформації важливий людський капітал. Тобто зріс попит не тільки на новітні технології, але і на тих, хто здатен їх продукувати. У результаті такої зміни пріоритетів висуваються підвищені вимоги до освітньої галузі, особливо до вищої освіти, її ефективної організації та управління. Тому відбувається реформа вітчизняної освітньої системи, яка покликана створити “умови для посилення співпраці державних органів і бізнесу з закладами вищої освіти на принципах автономії закладів вищої освіти, поєднання освіти з наукою та виробництвом 3 метою підготовки конкурентоспроможного людського капіталу для високотехнологічного та інноваційного розвитку країни, самореалізації особистості, забезпечення потреб суспільства, ринку праці та держави у кваліфікованих фахівцях" [5].

Суспільні трансформації ведуть до організаційних трансформацій, трансформацій систем управління, адже “еволюція управління є одночасно похідною та складовою еволюції суспільства" [6, с.26]. Вчені I. Адізес [1], К. Бланшар [2], Дж. Коллінз [12] та ін. найвищий еволюційний рівень управління назвали лідерством. Вивченню феномену лідера й теорій лідерства присвячені праці таких закордонних вчених, як М. Дафт, Дж. Гибсон, К. Дэвис, Дж. Максвел, П. Мучинські, Т. Бендас, та вітчизняних В. Барко, Т. Дуткевич, Л.Карамушка, О. Романовський та ін.

Особливості лідерства в освітньому менеджменті (e-leadership) досліджували Л. Болден, С. Калашникова, Л. Карамушка та ін. [3. 4, 7, 8, 9, 13]. Застосування лідерської парадигми в управлінських процесах в освіті описали в своїх роботах вітчизняні вчені І. Зязюн, В. Кремень, О. Савченко та ін. Проте ще недостатньо вивчена проекція сучасних теорій лідерства на освітній простір.

Постановка завдання. Метою статті $є$ дослідження сучасного освітнього лідерства в закладах вищої освіти (ЗВО).

Результати. Не існує єдиної дефініції поняття лідера як і немає єдиної теорії лідерства. Науковцями було розроблено майже 70 класифікаційних систем, кожна 3 яких має свої підходи до визначення лідерства [17]. Оскільки це суспільноособистісний феномен, то з розвитком суспільства з'являються нові теорії лідерства. Розглянемо ті з них, які найчастіше проявляються в сучасних управлінських процесах.

Трансформаційна теорія: лідерство розглядається як процес, за допомогою якого лідер взаємодіє з іншими і при цьому створює зв'язок, який посилює мотивацію як послідовників, так і лідера. При цьому лідер має бути уважним до потреб і мотивів послідовників, намагаючись допомогти їм досягти свого максимального потенціалу. А також лідери можуть ініціювати та впроваджувати важливі зміни (трансформації) в організації. Цю теорію порівняють 3 теорією харизматичного лідерства. Харизматичний лідер не тільки здатний надихати і мотивувати співробітників до діяльності, але разом зі своїми послідовниками створює корпоративні цінності, формує корпоративну культуру організації, яка грунтується на взаємній довірі та підтримці. 
Транзакиійна теорія: зосередження лідерів на організації і контролі групової діяльності; керування за допомогою винагород i покарань. Ця теорія часто прирівнюється до концепції та практики управління й залишається надзвичайно поширеним компонентом багатьох моделей лідерів та організаційних структур.

Лідерство в командi: лідер керує командою за допомогою відмінних комунікаційних задатків та вмінь, при цьому не обмежує членів команди у виборі шляхів та методів досягнення цілей.

Теорія навичок: вивчені знання та набуті навички, вміння є визначальними чинниками в практиці ефективного лідерства.

Ситуащійне лідерство: лідери вибирають найкращий курс дій залежно від ситуаційних факторів, при цьому використовують не єдиний стиль лідерства.

Теорія непередбачених ситуачій: ефективність лідера залежить від того, наскільки добре стиль лідера відповідає певній ситуації. Відмінність від ситуаційного лідерства у тому, що в ситуаційній теорії увага зосереджена на адаптації до ситуації, а в теорії непередбачених випадків - ефективність керівництва залежить від ступеня відповідності якості та стилю лідера ситуації.

Теорія лідерства служіння: ця концепція лідерства відображає філософію, за якою керівники повинні бути слугами тих, ким керують. Тобто лідери повинні поставити потреби послідовників, клієнтів та громади вище за свої власні інтереси.

Повномасштабне керівництво (змішаний стиль): поєднання особливостей транзакційного та трансформаційного лідерства в єдиному комплексному підході, як того вимагає ситуація. Це дає можливість максимально задіяти переваги обох методів лідерства.

Змішаний підхід схожий із ситуаційним лідерством. Але змішана теорія полягає у виборі найкращого стилю лідерства між двома, які набуті, тоді як ситуаційне керівництво припускає використання найкращого керівництва, що можливе у конкретній ситуації. Ситуаційне та змішане лідерства дозволяють максимально використовувати свій лідерський потенціал і краще виконувати свої обов'язки. У таблиці 1 наведено сучасні суб-концепції теорій лідерства.

\section{Новітні суб-концепції теорій лідерства*}

Таблиця 1

Table 1

Newest sub-concepts of leadership of leadership theories*

\begin{tabular}{|l|l|l|}
\hline \multicolumn{1}{|c|}{ Назва теорії } & \multicolumn{1}{|c|}{ Автори } & \multicolumn{1}{c|}{\begin{tabular}{c}
\multicolumn{1}{c|}{ Рік } \\
Впровадження
\end{tabular}} \\
\hline емоційний інтелект & $\begin{array}{l}\text { П. Саловей, Д. Майер, } \\
\text { Д. Гоулман }\end{array}$ & $1995 \mathrm{p.}$ \\
\hline гарячі групи & Дж. Ліпман-Блюмен & $1995 \mathrm{p}$. \\
\hline сполучне лідерство & Дж. Ліпман-Блюмен & $1997 \mathrm{p}$. \\
\hline двигун лідерства & Н. Тічі & $1997 \mathrm{p}$. \\
\hline опосередковане лідерство & $\begin{array}{l}\text { Р. Фішер, } \\
\text { А. Шарп }\end{array}$ & $1998 \mathrm{p}$. \\
\hline розподілене лідерство & $\begin{array}{l}\text { Д. Бредфорд, } \\
\text { А. Коен }\end{array}$ & $1998 \mathrm{p}$. \\
\hline внутрішнє стимулювання & К. Кешман & $2001 \mathrm{p.}$. \\
\hline первинне лідерство & $\begin{array}{l}\text { Д. Голман, } \\
\text { Р. Бояцис }\end{array}$ & $2002 \mathrm{p}$. \\
\hline $\begin{array}{l}\text { лідерство як управління } \\
\text { парадоксами }\end{array}$ & $\begin{array}{l}\text { Ф. Тромпенаарса, } \\
\text { Ч. Хемпден-Тернера }\end{array}$ & $2002 \mathrm{p}$. \\
\hline
\end{tabular}

* систематизація автора. 
За останні роки спостерігається переорієнтація основ теорій лідерства із значимості особистісного фактора на пріоритетність команди та організації в цілому. Якщо раніше лідерство ототожнювали або 3 особистістю лідера, або із соціальним процесом, то сучасні дослідження будуються на інтеграції цих двох підходів. Зокрема це прослідковується в освітньому менеджменті, оскільки в освітніх процесах лідерство $\epsilon$ наслідком процесу управління. У цьому випадку керівник стає лідером не завжди в силу особистісних переваг. Під дією інших факторів він набуває лідерських рис задля виконання покладених на нього обов'язків. Тобто процес формує лідера. Водночас для успішної реалізації процесу, для виконання організацією своєї освітньої місії потрібний лідер із сформованою управлінською компетентністю. Від моделей лідерства з одним складником - “керівник-лідер", двохскладової моделі “керівник-лідер - послідовники" необхідно перейти до тріади “лідер - послідовники - процес управління” (рис.1). У такий спосіб актуалізується лідерство, в основі якого лежать взаємозв'язки та взаємодія у колективі, досягнення спільних цілей, здатність до змін та інновацій.

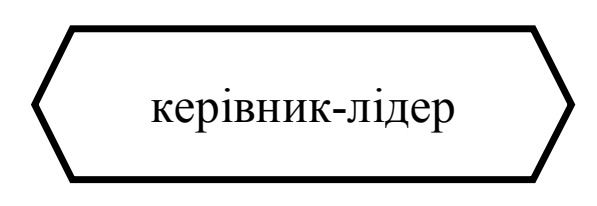

а) односкладова модель;

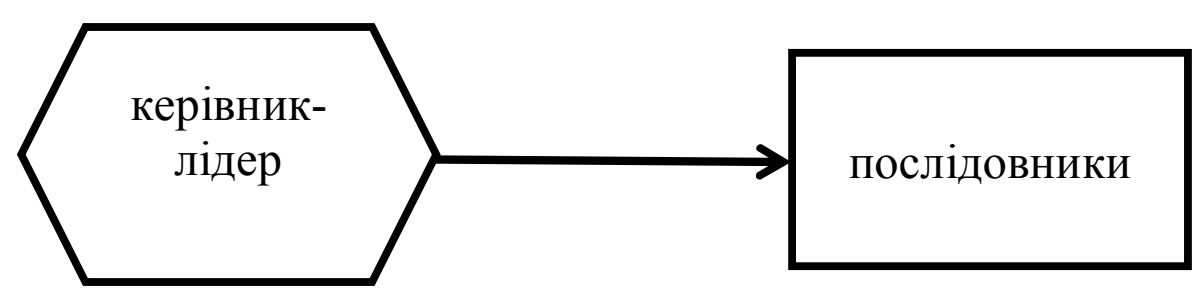

б) двохскладова модель;

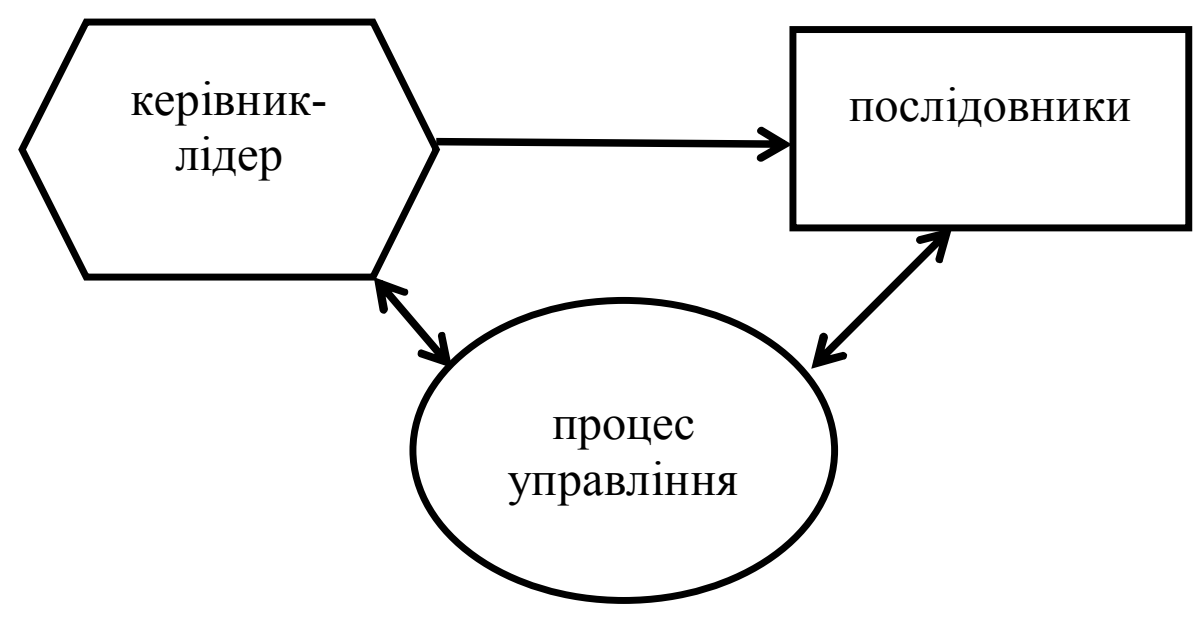

в) трьохскладова модель.

Puc. 1. Еволюція моделі лідерства в організації

Fig. 1. Evolution of the leadership model in the organization*

${ }^{*}$ Складено автором на основі $[15$, с. 31$]$ 
Освітня галузь $є$ особливою, порівняно із іншими галузями економіки [16]. Поперше, у ЗВО продукується найпотрібніший для сучасної економіки продукт - нові знання, інновації. По-друге, людські ресурси у ЗВО характеризуються високим інтелектом, розвиненими комунікативними здібностями, постійно займаються саморозвитком, мають розвинені лідерські здібності. Тому управління в ЗВО має свої особливості: “лідери - це люди, які мають цілі, мотивації та дії” [14]; науковопедагогічні працівники важче піддаються управлінню, не сприймають психологічного та управлінського тиску, мають високу схильність до протистояння змінам. Це вимагає від освітнього лідера гнучкості, постійного саморозвитку, підвищення рівня ділової комунікації, оновлення методів мотивації працівників. У [11] шотландськими дослідниками розроблена модель особистості освітнього лідера, за якою лідер в ЗВО має задовольняти таким вимогам: відповідність (професійну, академічну), цікавість, колегіальність, обдарованість, характер, впевненість.

На думку Л.М. Карамушки і Т.Г. Фелькель “ефективність діяльності сучасних організацій системи вищої освіти значною мірою залежить від діяльності керівників (ректорів, проректорів, деканів, зав. кафедрами тощо), використання ними інноваційних підходів в управлінні. Одним із таких підходів $є$ підхід, який базується на розумінні керівника вищої освіти як лідера" [10]. Пропонуємо наступну типізацію лідерів 3ВО:

1) ті, хто має формальну ієрархічну владу (вертикальний вплив зверху вниз);

2) ті, хто має міжособистісний вплив (горизонтальний вплив);

3) ті, хто має високу академічну репутацію: відомі науковці, очільники наукових шкіл, наукових груп (академічний вплив);

4) харизматичні особи, які не належать до управлінської ієрархії ЗВО (індивідуальний вплив);

5) ті, хто має вплив за межами ЗВО - соціальний, політичний, фінансовий (займаються політикою, активні у суспільному та культурному житті громади, меценати).

Зауважимо, що академічне лідерство властиве тільки освітнім системам. Водночас, просування управлінською ієрархією вгору в ЗВО також можливе лиш через академічний шлях (згідно із [5]), що може в окремих випадках гальмувати розвиток організації. Проектуючи теорії лідерства на описані типи лідерів у 3ВО, одержимо, що: 1-ий тип підпорядковується транзакційній теорії або повномасштабному керівництву; 2-ий тип - змішаному стилю, 3-й тип - трансформаційному стилю та/або лідерству в команді; 4-ий тип - харизматичній теорії; 5-ий тип - ситуаційній та/або харизматичній теopiï.

Спеціалісти 3 менеджменту стверджують, що необхідна умова сучасного ефективного управління полягає у розвитку командної роботи за принципом «не контроль, а довіра!». Справжній лідер в освіті має довіру від своєї команди, вірить в себе і в команду, вміє швидко пристосовуватися до змін, має стратегічне і адаптивне мислення, харизматичні здібності.

Висновки. Сучасні зміни характеру та організації праці зумовлюють зміну правил і принципів управління та лідерства, що в свою чергу висуває нові вимоги до особистості та діяльності лідера. Трансформації підлягає й інститут лідерства в освітній галузі. Запропонована класифікація типів освітніх лідерів дозволяє визначити відповідний стиль керівництва та модифікувати його залежно від стратегічних цілей організації. Надалі є потреба детальнішого вивчення роботи кожного типу лідера по формуванню та розвитку команди. 
1. Адізес I. Ідеальний керівник: чому ви не можете стати ним, і що робити з цього приводу: нова парадигма менеджменту / І. Адізес. - К. : Вид. дім «Києво-Могилянська академія», 2006. - 266 с.

2. Бланшар К. Лидерство: к вершинам успеха / К. Бланшар. - Санкт-Петербург : Питер, 2008. - 368 с.

3. Bolden Richard, Petrov Georgy, Gos Jonathan. Tensions in higher education leadership: towards a multilevel model of leadership practice // Paper presented at the Annual Conference of the Society for Research into Higher Education (SRHE), December 2007.

4. Eacott Scott. Educational Leadership Relationally. Sense publishers Rotterdam- Boston - Taipei, 2015. $31 \mathrm{p}$.

5. Закон України «Про вищу освіту» (2014) [Електронний ресурс]. Режим доступу: http://zakon2.rada.gov.ua/laws/ show/1556-18.

6. Калашнікова С. А. Освітня парадигма професіоналізації управління на засадах лідерства : монографія / С А. Калашнікова. - К. : Київськ. ун-т імені Бориса Грінченка, 2010. - 380 с.

7. Калашникова С., Жданова К. Врядування у вищій освіті: сутність, виміри, тенденції / С. Калашникова, К. Жданова // Вища освіта України. - 2013. - № 3 (дод. 2). - Тематичний випуск “Свропейська інтеграція вищої освіти України в контексті Болонського процесу”. - С.69-74.

8. Карамушка Л. М. Психологія управління закладами середньої освіти : монографія / Л. М. Карамушка. - К. : Ніка-Центр, 2000. - 332 с.

9. Карамушка Л.М. Формування конкурентоздатної управлінської команди (на матеріалі діяльності освітніх організацій) : монографія / Л.М. Карамушка, О.А. Філь. - К. : ІНКОС, 2007. - 268 с.

10.Карамушка Л.М. Лідерство в організації: аналіз основних підходів та важливість їх застосування в організаціях системи вищої освіти / Л. М. Карамушка, Т. Г. Фелькель // Проблеми сучасної психології. - 2013. - № 2. - С. 52-60.

11. Kennie T. Academic leadership: Dimensions and dynamics / Dr. Tom Kennie // ENGAGE: ISSUE 21, 2010 [Електронний ресурс]. Режим доступу: http://www.bristol.ac.uk/medialibrary/sites/staffdevelopment/ documents/AcademicLeadership_Dimension\&Dynamics.pdf

12.Коллинз Дж. От хорошего к великому / Дж. Коллинз. - СПб. : Стокгольмская школа экономики в Санкт-Петербурге, 2002. - 303 с.

13.Критсонис В.А. Психология лидерства в образовательных учреждения / В.А. Критсонис // Лидерство. Психологические проблемы в бизнесе: По материалам американских исследований / Редакторы-составители К.Ковальски, Дж. Кенджеми. - Дубна: Издательский центр «Феникс», 1997. - C.155-164.

14.Cuban L. The Manageria 1 Imperative and the Practice of Leaders hip in Schools. Albany, NY: State University of New York Press, 1988.

15.Линьов К. О. Лідерство у контексті еволюції підходів до осмислення феномену в освіті / К. О. Линьов // Scientific Journal «ScienceRise: Pedagogical Education», 2016. - № 8(4). - C. 29-34.

16. McNay I. Ultimate FE Leadership and Management Handbook / Ian McNay, Jill Jameson - Continuum International Publishing Group Ltd., 2007. - 192 p.

17. Northouse P. G. Leadership: Theory and Practice / Peter G. Northouse - 7th edition: Western Michigan University, 2016. -520 p.

\section{References}

1. Adizes, I. Ideal leader: why you can not become and what to do about it: a new management paradigm, Vyd. dim «Kyyevo-Mohylyanska akademiya», 2006.

2. Blanchar, K. Leadership: to the Summit of Success, Piter, 2008.

3. Bolden, Richard, Petrov, Georgy, and Jonathan Gos. "Tensions in higher education leadership: towards a multi-level model of leadership practice". Paper presented at the Annual Conference of the Society for Research into Higher Education (SRHE) December 2007.

4. Eacott Scott. Educational Leadership Relationally. Sense publishers Rotterdam- Boston - Taipei, 2015.

5. "On Higher Education. Law of Ukraine vid 09.04.2015." The Verkhovna Rada of Ukraine, zakon4.rada.gov.ua/laws/show/1556-18. Accessed 2 Mar. 2018.

6. Kalashnikova, S. A. Educational paradigm of professionalization of management on the basis of leadership, Kyivsky un-t imeni Borysa Hrinchenka, 2010.

7. Kalashnikova, S., and K. Zhdanova. "Management in Higher Education: Essence, Measurements, Trends." Vyshcha osvita Ukrayiny, no. 3 (add. 2), 2013, pp.69-74.

8. Karamushka, L. M. Psychology of management of institutions of secondary education: monohraphiya, Nika-Center, 2000.

9. Karamushka, L.M., and O.A. Fil. Formation of a competitive management team (based on the work of educational organizations), INKOS, 2007. 
10.Karamushka, L.M., and T.N. Felkel "Leadership in the organization: analysis of the main approaches and the importance of their application in organizations of the higher education." Problemy suchasnoyi psykholohiyi, no. 2, 2013, pp. 52-60.

11.Kennie, T. "Academic leadership: Dimensions and dynamics." ENGAGE: no.21, 2010. University of Bristol, $\quad$ www.bristol.ac.uk/media-library/sites/staffdevelopment/ documents/AcademicLeadership_Dimension\&Dynamics.pdf Accessed 2 Mar. 2018.

12.Collins, J. From Good to Great, Stockholm School of Economics in St. Petersburg, 2002.

13.Kritsonis, V.A. "Psychology of leadership in educational institutions". Leadership. Psychological problems in business: Based on American research, Izdatel'skiy tsentr «Feniks», 1997, pp.155-164.

14.Cuban, L. The Manageria l Imperative and the Practice of Leaders hip in Schools, State University of New York Press, 1988.

15.Lyniov, K.O. "Leadership in the context of the evolution of approaches to understanding the phenomenon in education." Scientific Journal "ScienceRise: Pedagogical Education", no. 8 (4), 2016, pp. 29-34.

16.McNay, I., and Jill. Jameson. Ultimate FE Leadership and Management Handbook, Continuum International Publishing Group Ltd., 2007.

17.Northouse, P. G. Leadership: Theory and Practice. 7th ed. Western Michigan University, 2016.

\title{
Рецензенти:
}

Якубів В.М. - д.е.н., професор, завідувач кафедрою управління та бізнес-адміністрування ДВНЗ "Прикарпатський національний університет імені Василя Стефаника";

Кондур О. С. - к.ф.-.м.н., доцент кафедри економічної кібернетики ДВНЗ “Прикарпатський національний університет імені Василя Стефаника".

УДК 657.21:37.014.3

ББК 74.052 Кондур О. С. , Цюпа О.П.

ФІНАНСОВЕ ЗАБЕЗПЕЧЕННЯ ОСВІТИ І НАУКИ В УМОВАХ ОСВІТНЬОЇ РЕФОРМИ

\author{
'ДВНЗ “Прикарпатський національний університет імені \\ Василя Стефаника", \\ Міністерство освіти і науки України, \\ педагогічний факультет, \\ вул. Шевченка, 57, м. Івано-Франківськ, \\ 76018, Україна, \\ тел.: +380509104948, \\ e-mail: oxikon13@gmail.com \\ ДВН3 “Прикарпатський національний університет імені \\ Василя Стефаника", \\ Міністерство освіти і науки України, \\ кафедра фінансів, \\ вул. Шевченка, 57, м. Івано-Франківськ, \\ 76018, Україна, \\ тел.: +380662625148, \\ e-mail: oxikon13@gmail.com
}

Анотація. Реформа освітньої галузі України полягає у формуванні нового покоління фахівців для національної та міжнародної економіки. Результати трансформацій в освіті повинні вплинути на розвиток економіки та суспільства в цілому.

У статті проаналізовано основні етапи освітньої реформи. Описано законодавчо передбачене фінансове і матеріально-технічне забезпечення системи освіти і науки. На 